\title{
Improving Students' Writing Skills and Motivation in Learning English at SMAN 2 Kediri Using Hypnoteaching Strategy
}

\author{
Aprilia Rosmarie ${ }^{1, *}$, Mualimin \\ Diponegoro University- Jl. Prof. H. Soedarto, SH, Tembalang Semarang, 50275 Indonesia \\ ${ }^{1}$ rosemariesahetapy@gmail.com* \\ * corresponding author
}

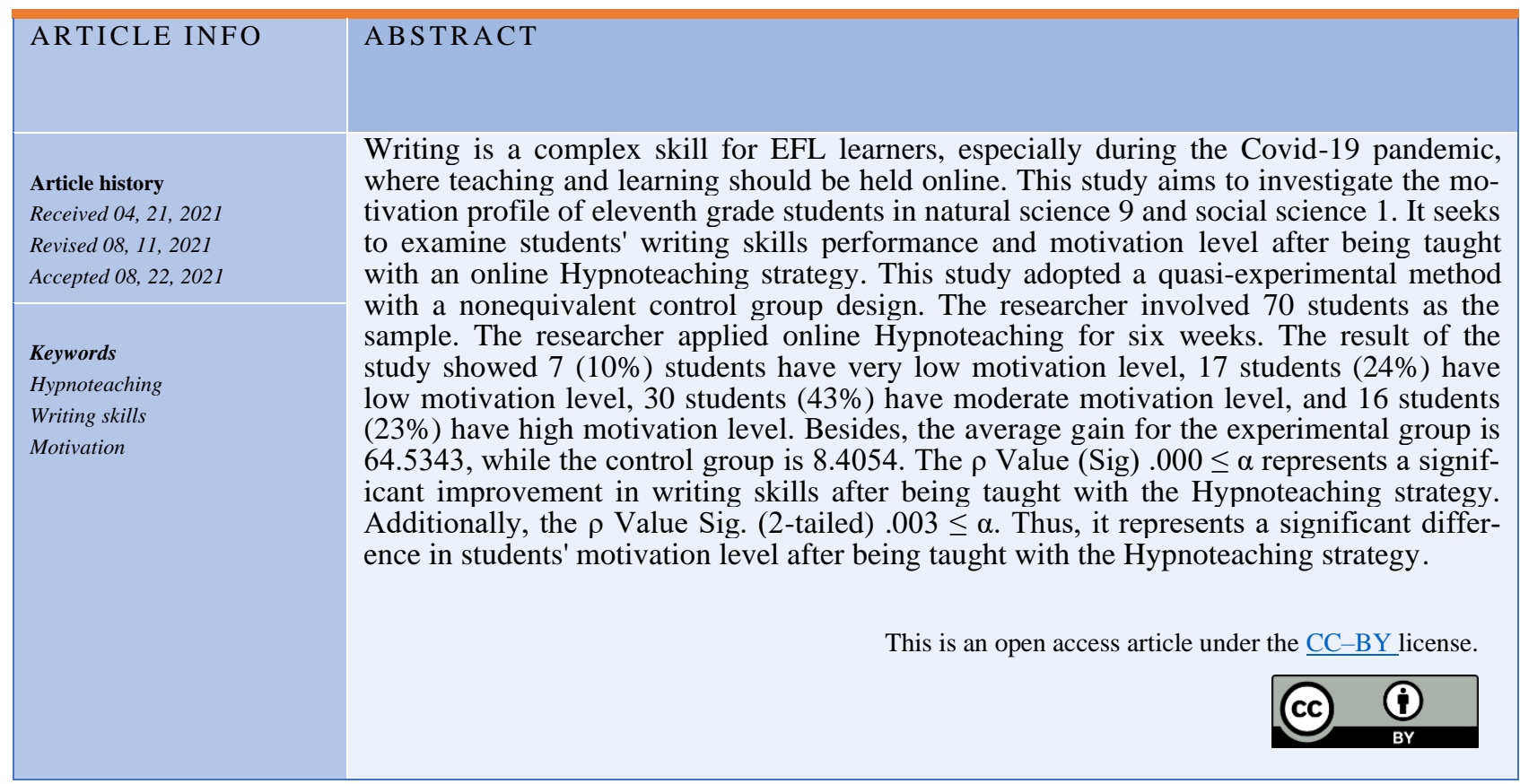

\section{Introduction}

The ability to use the English language is required. Currently, it is essential to be competent and communicate effectively in written or oral using English. (Hyland, 2019) found that writing is the most conflicting or daunting language skill for students, especially EFL learners. From March until October, the high schools in Kediri are obligated to conduct online learning or PJJ (Pembelajaran Jarak Jauh). Consequently, it requires a lot of internet data, a stable signal, and a long period of time. The teacher should encourage students' motivation in learning conducted online. Mohd, Goh \& Fathi as cited by Ergün \& Avc1, (2018); Mangesa R.T., (2018) mentioned that motivation is an inside force in deciding the bearing of the persuading act and energizing the appropriate behavior.

One method that can be used to enhance students' writing skills is using the Hypnoteaching strategy. Hypnoteaching strategy activates students' learning skills by stimulating their conscious minds. Dj \& Sukarnianti, (2015) added that it helps both teachers and students. The teacher can create a relaxed atmosphere in learning, so the students do not feel any stress or burden in learning. Many researchers have applied the hypnoteaching strategy in their learning process, such as (Amaluddin, 2019; Asteria et al., 2018; Dj \& Sukarnianti, 2015; Zahro et al., 2019), and so forth. However, no researchers have investigated students' improvement in writing skills and students' motivation level using the Hypnoteaching strategy. Hence, this study investigates that aspect in the Indonesian classroom, particularly in Kediri city. Considering the importance of writing skills, this skill is improved chiefly in writing the narrative text for the secondary stage. Therefore, some research problems are drawn, as written below:

RQ1. What is the motivation profile of eleventhgrade natural science 9 and social science 1 students before being taught with Hypnoteaching strategy?

RQ2. Is there any significant improvement in the students' performance after being trained with Hypnoteaching method in writing skills?

Therefore, this study aims to find out and analyze the students' motivation profile, the significant improvement of students' writing skills after being 
taught with Hypnoteaching strategy, and the substantial difference in students' motivation level in learning English, especially at the eleventh-grade Senior High School.

\section{Method}

\section{A. Participants}

The State Senior High School 2 Kediri was selected as the place of the research. The 1175 students were chosen as the researcher sample, while $35 \mathrm{elev-}$ enth-grade students from natural science 11 as the control group and 35 eleventh-grade students from social science 1 as the experimental group.

\section{B. Research Design}

This research was a quasi-experimental study using a nonequivalent control group design. The applied one group pretest-posttest design model by (Sugiyono, 2011) is presented below.

$$
\frac{01 \times 02}{0304}
$$

Where:

O1 : Experimental group (Before applying the treatment)

O2 : Experimental group (After applying the treatment)

X : Treatment (Applying the Hypnoteaching Strategy) ment)

O3 : Control group (Before applying the treat-

O4 : Control group (After applying the treatment)

In this research, the Hypnoteaching strategy acted as the independent variable. Meanwhile, the dependent variables were students' motivation and students' improvement in writing skills.

\section{Instruments and data collection}

Several instruments were used in this study.

1) a. Achievement test

It consisted of 6 questions, distributed through Google form. The test was adapted from Brown (2004) and their material book, entitled Bahasa Inggris: for grade XI from BSE revision edition in 2017.

\section{2) Motivational questionnaire}

The questionnaire form consisted of 28 closeended statements, adapted from Academic Writing Motivation Questionnaire (AWMQ) by (Payne, 2012). The questionnaire had been sent through the Google form. The questionnaire was classified into four factors of enjoyment, self-efficacy, instrumentality, and recognition.

\section{3) Interview process}

The researcher interviewed and recorded all the students' responses from the experimental class.

4) Video tape-recorded data.

The researcher used the Zoom application while conducted the research.

The data were obtained through the pilot test to another sample of the students in State Senior High School 2 Kediri from twelfth-grade natural science 9 class, conducted on 31st July 2020. Additionally, a pretest was carried out for the eleventh natural and social science students on 7th August 2020. The material used in this study was narrative text (introduction, generic structure, and so forth.). At least, the students wrote two legend stories and two personal writing about the covid-19 pandemic.

\section{Data Analysis}

To analyze the pilot test, the validity, reliability, discrimination, and difficulty level of the instrument were calculated using SPSS 24. Then, the researcher measured the validity of the instrument using Bivariate Pearson Correlation in SPSS 24. The results indicated that question number 1 was classified to have very high validity; questions number 2 and 3 had high validity; number 4 and 5 had moderate validity, and number 6 had low validity. Meanwhile, the validity test on the questionnaire revealed that item 6 had low validity; statements number 5,9,18,24 had very low validity; statements number $2,4,7,10,12$,$13,14,17,19,20,21,22,23,25,26,27$ had moderate validity; and the statements number 1,3,8,11,15,16,28 had high validity.

To calculate the reliability, the researcher used the Cronbach Alpha in SPSS 24 to find the reliability of the questionnaire items. The result showed that the reliability score of the questionnaire was .902. Thus, this motivation questionnaire is valid or acceptable. Then, the reliability of short answer and essay-test items was analyzed using SPSS 24 . The r-table score was 0,3291 , while the result of $\mathrm{r} 11$ was 0.627 . If the $\mathrm{r} 11 \geq \mathrm{r}$-table $0.627>0.3291$, then the instrument is classified as valid. Further information about the recapitulation of the pilot test's analysis results is presented in Table 1.

Table 1. Result Recapitulation of Pilot Test

\begin{tabular}{cccc}
\hline $\begin{array}{c}\text { Question } \\
\text { Number }\end{array}$ & $\begin{array}{c}\text { Difficulty } \\
\text { Level }\end{array}$ & Validity & $\begin{array}{c}\text { Discrimination } \\
\text { Index }\end{array}$ \\
\hline 1 & Medium & Very & 0.831 \\
& High & \\
2 & Easy & High & 0.650 \\
3 & Easy & High & 0.723 \\
4 & Medium & Moderate & 0.530 \\
5 & Medium & Moderate & 0.588 \\
6 & Medium & Low & 0.303 \\
\hline
\end{tabular}




\section{E. Hypothesis}

If $\mathrm{p}$ Value (Sig.) $\leq \alpha(0.05)$ : $\mathrm{H} 0$ is rejected. $\mathrm{H} 1$ is not rejected. It means there is a significant improvement in writing skills after being taught with Hypnoteaching strategy. If p-value (Sig.) $\geq \alpha(0.05)$ : $\mathrm{H} 0$ was accepted, meanwhile the H1 was rejected. Therefore, no significant improvement in students' writing skills was observed after being taught with the Hypnoteaching strategy. In contrast, if p-value Sig. (2-tailed) $\leq \alpha(0.05)$ : H2 was rejected, while the $\mathrm{H} 3$ was not rejected. It represented a significant difference in students' motivation level after being taught with the Hypnoteaching strategy. Additionally, if p-value Sig. (2-tailed) $\geq \alpha(0.05)$ : $\mathrm{H} 2$ is not rejected, and the $\mathrm{H} 3$ is rejected. It signified no significant difference in students' motivation level after being taught with the Hypnoteaching strategy.

\section{Results and Discussion}

\section{A. Is there any significant improvement of the students' performance after being taught with Hypnoteaching strategy in writing skills?}

The researcher already implemented, performed, and applied Hypnoteaching Strategy in Experimental Class (XI IIS 1) and applied the conventional method or did not do apply any treatment in control class (XI MIA 9). The pretest already conducted in both class on 7th August 2020 used Zoom and the students answered the test in Google Form link. The test conducted in one meeting, around 90 minutes. Then, the researcher applied the Hypnoteaching method in 6 meetings. Further, on 28th September 2020, the posttest conducted in control class (XI MIA 9) and the researcher distributed the posttest for experimental class (XI IIS 1) on 8th October 2020. After getting the score of pretest and posttest, the researcher did the statistical treatment data by calculating the normalized gain and test of normality. First, the researcher calculated the N-Gain score using SPSS 24. Here is the calculation of N-Gain score.

Table 2. Result of N-Gain Score

\begin{tabular}{|c|c|c|c|c|c|}
\hline \multicolumn{3}{|c|}{ Control Class } & \multicolumn{3}{|c|}{ Experimental Class } \\
\hline Mean & $\begin{array}{l}\text { Mini- } \\
\text { mum } \\
\text { Score }\end{array}$ & $\begin{array}{c}\text { Maximum } \\
\text { Score }\end{array}$ & Mean & $\begin{array}{l}\text { Mini- } \\
\text { mum } \\
\text { Score }\end{array}$ & $\begin{array}{l}\text { Maxi- } \\
\text { mum } \\
\text { Score }\end{array}$ \\
\hline 8.4054 & -46.51 & 35.94 & 64.5343 & 18.64 & 97.73 \\
\hline
\end{tabular}

Based on Table 2, the researcher concluded that the mean score of $\mathrm{N}$-Gain score in experimental class is 64.5343 or $64.5 \%$ and it can be concluded that this strategy, Hypnoteaching strategy is quite effective regarding to Classification of Normalized Gain by (Hake, 1999). Hake, (1999) classified that the range score in $56 \%-75 \%$ belongs to Quite Effective. Meanwhile, the mean score of N-Gain score in control class is 8.4054. It means that the conventional treatment in control class is not effective, because the score is below than $40 \%$.

To know if there was any significant improvement in writing skills after being taught with Hypnoteaching strategy or not, the researcher did the statistical hypothesis testing by using Independent Sample T-test formula. The researcher used SPSS 24 to calculate the data. Table 3 showed that the score of Sig. (2-tailed) is .000. According to the criteria of hypothesis testing that the researcher wrote in research methodology chapter, the researcher concluded if $\rho$ Value (Sig) $\leq \alpha(0.05)$, based on the result above it may be summarized $.000 \leq 0.05$, it means that $\mathrm{H} 0$ is rejected. $\mathrm{H} 1$ is not rejected. It means there is a significant improvement in writing skills after being taught with Hypnoteaching strategy.

Table 3. Result of Independent Sample T-Test

\begin{tabular}{|c|c|c|c|c|c|c|c|c|c|c|}
\hline \multicolumn{11}{|c|}{ Independent Samples Test } \\
\hline & & \multicolumn{2}{|c|}{$\begin{array}{l}\text { Levene's Test } \\
\text { for Equality } \\
\text { of Variances }\end{array}$} & \multicolumn{7}{|c|}{ t-test for Equality of Means } \\
\hline & & $F$ & Sig. & $t$ & $D f$ & $\begin{array}{c}\text { Sig. } \\
(2- \\
\text { tailed })\end{array}$ & $\begin{array}{c}\text { Mean Dif- } \\
\text { ference }\end{array}$ & $\begin{array}{l}\text { Std. Error } \\
\text { Difference }\end{array}$ & $\begin{array}{c}95 \% \text { Confi- } \\
\text { dence Interval } \\
\text { of the Differ- } \\
\text { ence }\end{array}$ & $F$ \\
\hline & & & & & & & & & Lower & Upper \\
\hline \multirow[t]{2}{*}{$\begin{array}{l}\mathrm{N}- \\
\text { Gain }\end{array}$} & $\begin{array}{c}\text { Equal variances } \\
\text { assumed }\end{array}$ & .010 & .921 & 11.389 & 68 & .000 & 56.12883 & 4.92845 & 46.29427 & 65.96340 \\
\hline & $\begin{array}{c}\text { Equal variances } \\
\text { not assumed }\end{array}$ & & & 11.389 & 67.983 & .000 & 56.12883 & 4.92845 & 46.29423 & 65.96344 \\
\hline
\end{tabular}

In this research, it may conclude that hypnoteaching strategy was successful and gave significant different to help students increasing their writing skills especially in narrative text. The researcher picked up an example of students' writing, and it showed that there was a good improvement in his writing. An example of students' writing and its improvement is presented in Fig. 1 and 2. 


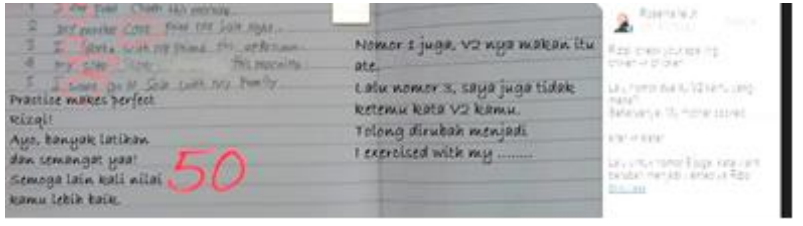

Fig. 1.Example of Students' Writing before the Hypnoteaching

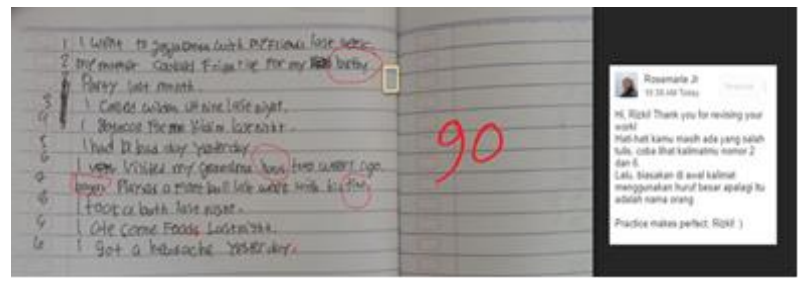

Fig. 2.Example of Students' Writing after the Hypnoteaching

One of the stages in hypnoteaching is giving compliments or positive suggestions in learning. (Yustisia, 2012) said that positive words foster students' minds to be relaxed and help them to be comfortable learning. Creating a relaxed and comfortable atmosphere is one of the keys to formal hypnosis, as stated by (Budianto \& Setya Wiratama, 2017). Positive suggestions, compliments, or appraisals are continuously provided to the students. The example of the positive words is illustrated in Excerpt 1.

\section{- Excerpt 1:}

"Miss April is appreciative. After we finish our assignments, she always said appreciative words, such as "thank you for completing the assignments, I hope your works are improved in the future.' Those kind words boost our motivation to learn. It made us feel appreciated. We are happy to have a kind teacher "Vika, 17 years old".

Clough, (2007) explains that by giving positive words, the students will not feel intimated and stifling interaction. Diantari et al., (2014) added that using positive suggestions in learning can encourage and stimulate students to get better scores. The study results suggest that students' writing score or writing performance in class has been improved. The study results also signify that positive appraisal or expression helps teachers get students' attention and respect. Further, Hakim, (2010) stated that the first phase of the hypnosis method is getting students' attention to master their hearts. Based on field observation and interview results, most of the students admire the teaching method, as explained in Excerpts 2 to 4.

- $\quad$ Excerpt 2:

"Mmm, maybe all of the teacher's methods are special for me. It made us relaxed. It is great, Miss" Ardi, 17 years old".

- Excerpt 3:
"For me, the teaching is great. It motivates me to attain my dream "Evi, 17 years old".

- Excerpt 4:

"The teacher is really kind. She has good English and uses a warm tone of language. During the teaching. The teacher also involves jokes "Bagus, 16 years old".

McNeely, (2015) explains that humor can effectively attract students' attention in the learning process. It should be included in the teaching process to generate a relaxed atmosphere in the classroom. A reclining classroom is substantial, especially in writing class (Neuman et al., 2000). Further, Yustisia, (2012) argued that the excellent benefit of hypnoteaching is that its facilitates students to master the material because they will feel motivated in learning, as confirmed by Evi (17 years old) in Excerpt 5. The teacher has a crucial role in helping the students to improve their skills, especially in learning. Clay, (2001) added that teacher modeling and presentation are essential to support students' understanding of writing. This study continuously observes and monitors students' achievement in writing. The interview results indicate that students attain positive impacts from the learning, as written in Excerpts 5 to 7.

- Excerpt 5:

"I can better comprehend the short story because the assigned tasks help me to understand them "Lutfi, 16 years old".

- Excerpt 6:

"....... Besides, the teacher used a shared screen to explain the materials "Nashwa, 16 years old".

- Excerpt 7:

The teacher implements a great teaching approach. She mentions the materials we are going to learn. Besides, she also uses a relaxing and clear teaching method "Wildan, 17 years old". In addition, the interview results also indicate the differences among the material presentation used in this study and the ones used by other teachers. The interview results are shown in Excerpts 8 and 9.

- Excerpt 8:

"The presentation used by this teacher is different from the other teachers "Wildan, 17 years old".

- Excerpt 9:

"The teacher uses Zoom in the teaching process, so we can feel the face-to-face atmosphere. Meanwhile, other teachers do not use this application. That is my favorite part. "Sherlynda, 17 years old".

During this pandemic situation, the teachers conducted online learning. However, most of them distributed the material or task through WhatsApp Mes- 
senger to the class captain and gave the deadline to submit the assignment. Based on the interview, many students complained and were frustrated because of many tasks in online learning. They uttered and felt the same feeling with Sherlynda (17 years old). Most of them explain that the teachers often give the task with minimum or no material explanation. By using creative PowerPoint presentations to aid the teaching process, an interactive and interesting learning process can be generated (Raja \& Nagasubramani, 2018). This study adopted the Hypnoteaching strategy online to monitor students' improvement in learning, even though many obstacles, such as the signal, time, and internet quota, have occurred.

B. The significant difference observed in students' motivation level after being taught with

\section{Hypnoteaching strategy.}

This study seeks to compare the previous motivation score of the experimental group from eleventhgrade social science 1 and the posttest score after the students have attended learning using the Hypnoteaching strategy in English subjects. The pretest results of the experimental group are shown in Table 4.

Table 4. Students' Pretest Motivation Level in the Experimental Group

\begin{tabular}{cccc}
\hline No. & $\begin{array}{c}\text { Range } \\
\text { Score }\end{array}$ & Interpretation & $\begin{array}{c}\text { Total of Stu- } \\
\text { dents }\end{array}$ \\
\hline 1. & $28-48$ & Very Low & 5 \\
2. & $56-62$ & Low & 7 \\
3. & $65-77$ & Moderate & 15 \\
4. & $79-84$ & High & 8 \\
\hline \multicolumn{4}{c}{ Total of Students } \\
\hline
\end{tabular}

After applying the Hypnoteaching strategy in six meetings, the researcher distributed the motivation questionnaire on 1st October 2020. It aims to investigate the improvement on students' motivation score after attending the learning using hypnoteaching method. The posttest results are illustrated in Fig. 3. The scores illustrated in Fig. 3 are categorized using the category shown in Table 5. The data indicate improvement of students' motivation level after being taught with Hypnoteaching. Further, statistical hypothesis testing was carried out to check the possible significant improvement. The students' posttest and pretest scores were calculated and compared using Paired-Sample T-Test. The results of that calculation are shown in Table 6.

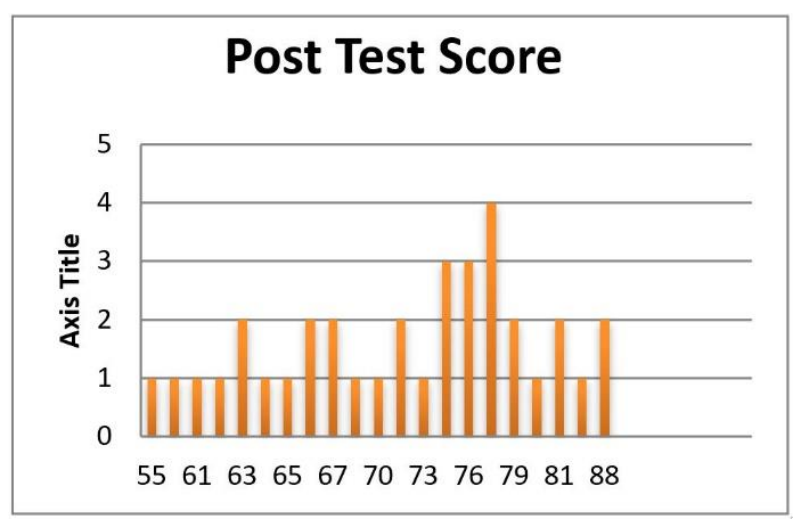

Fig. 3. Students' Motivation Score

Table 5. Range Score of Motivation Level of Experimental Group

\begin{tabular}{cccc}
\hline No. & $\begin{array}{c}\text { Range } \\
\text { Score }\end{array}$ & Interpretation & $\begin{array}{c}\text { Total of Stu- } \\
\text { dents }\end{array}$ \\
\hline 1. & $28-48$ & Very Low & 0 \\
2. & $49-62$ & Low & 4 \\
3. & $63-76$ & Moderate & 19 \\
4. & $77-91$ & High & 11 \\
\hline \multicolumn{3}{c}{ Total of Students } & 35 \\
\hline
\end{tabular}

Table 6. Range Score of Motivation Level of Experimental Group

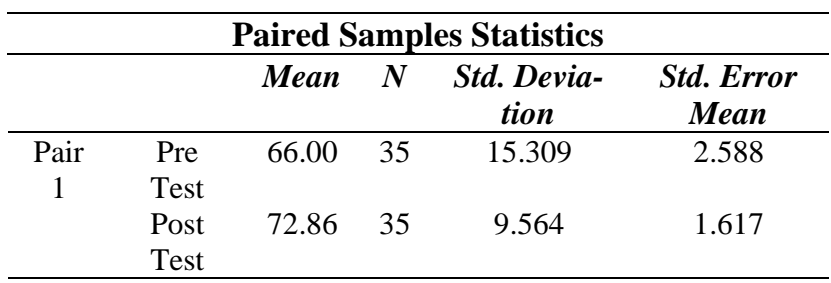

The average scores for the pretest and post-test are 66.00 and 72.86, respectively. It shows that the posttest score is more significant than the pretest score, $72.86>66.00$. Then, the results were calculated using Sig. (2-tailed) to identify the significant difference in students' motivation scores. The results of that calculation are presented in Table 7 .

Table 7. Sig. (2-tailed) Results.

\begin{tabular}{|c|c|c|c|c|c|c|c|c|c|}
\hline & \multicolumn{5}{|c|}{ Paired Differences } & \multirow[t]{3}{*}{$\mathbf{t}$} & \multirow[t]{3}{*}{ df } & \multirow{3}{*}{$\begin{array}{l}\text { Sig. (2- } \\
\text { tailed) }\end{array}$} \\
\hline & & \multirow[t]{2}{*}{ Mean } & \multirow[t]{2}{*}{$\begin{array}{c}\text { Std. Devia- } \\
\text { tion }\end{array}$} & \multirow[t]{2}{*}{$\begin{array}{c}\text { Std. Error } \\
\text { Mean }\end{array}$} & \multicolumn{2}{|c|}{$\begin{array}{l}\text { 95\% Confidence Interval of the } \\
\text { Difference }\end{array}$} & & & \\
\hline & & & & & Lower & Upper & & & \\
\hline $\begin{array}{c}\text { Pair } \\
1\end{array}$ & $\begin{array}{l}\text { Pre-Test - } \\
\text { Post Test }\end{array}$ & $\begin{array}{c}- \\
6.857 \\
\end{array}$ & 12.733 & 2.152 & -11.231 & -2.483 & $\begin{array}{c}- \\
3.186\end{array}$ & 34 & .003 \\
\hline
\end{tabular}


The result shows that the Sig. (2-tailed) the score is .003 . Based on the criteria of hypothesis testing that the researcher used, if $\rho$ Value Sig. (2-tailed) $\leq \alpha$ $(0.05)$, then the $\mathrm{H} 2$ is rejected, and $\mathrm{H} 3$ is accepted. Therefore, a significant difference in students' motivation level has been confirmed after being taught with the Hypnoteaching strategy. The result is supported by the mean score difference in this experimental class's pretest and posttest scores. Huang et al., (2016) mentioned that by having high motivation in learning, it can help students to pay more attention on the lessons that they learn as agreed by (Alamer $\&$ Lee, 2019).

\section{Conclusion}

Hypnoteaching strategy helps the students in education, primarily in improving their writing skills. Hypnoteaching operates by the continuous appraisal, attention, jokes, warm language, good feedback, positive words, and creating a relaxed and enjoyable atmosphere in the learning process. In addition, technology has a positive impact on education. Thus, both teachers and students should seize these good impacts and eliminate the adverse effects instead. The study observes that online teaching using the Hypnoteaching strategy helps students have more significant learning motivation, mainly when the teacher displays the motivational video. Visual images better increase students' motivation level in writing than words.

\section{References}

Alamer, A., \& Lee, J. (2019). A motivational process model explaining L2 Saudi students' achievement of English. System, 87(December), 102133.

Amaluddin, M. (2019). Pengaruh metode pembelajaran hypnoteaching terhadap kemampuan menulis pantun oleh siswa kelas xi SMK Pab 6 Medan. Bahastra, Jurnal Pen-Didikan Bahasa Dan Sastra Indonesia, 4(1), 275 - 279.

Asteria, P. V., Rohmah, S. K., \& Renhoran, F. Z. (2018). Penerapan metode hypnoteaching dalam pembelajaran bermain peran siswa kelas V SDN Lidah Kulon IV Kecamatan Lakarsantri Surabaya. Jurnal Pendidikan (Teori Dan Praktik, 2(2), 150 - 155.

Budianto, A., \& Setya Wiratama, N. (2017). Hypnoteaching dalam pembelajaran Sejarah. Jurnal Pendidikan Edutama, 4(2), 1-9.

Clay, M. M. (2001). Change over time in children's literacy development. Heinemann.
Clough, M. P. (2007). What is so important about asking questions?. Iowa Science Teachers Journal, 34(1), 2-4.

Diantari, P., Wiarta, I. W., Negara, I. G. A. O., \& Ke, S. P. M. (2014). Pengaruh model pembelajaran problembased learning berbasis Hypnoteaching terhadap hasil belajar Matematika siswa kelas v SD Gugus 1 Kuta Utara. Mimbar Pgsd Undiksha, 2(1).

Dj, M. Z., \& Sukarnianti, S. (2015). Using Hypnoteaching strategy to improve students' writing ability. Dinamika Ilmu, 15(2), 185-199.

Ergün, E., \& Avc1, Ü. (2018). Knowledge sharing selfefficacy, motivation and sense of community as predictors of knowledge receiving and giving behaviors. Journal of Educational Technology \& Society, 21(3), 60-73.

Hake, B. J. (1999). Lifelong learning in late modernity: The challenges to society, organizations, and individuals. Adult Education Quarterly, 49(2), 7990.

Hakim, A. (2010). Hypnosis in teaching: Cara dahsyat mendidik \& mengajar. Visi Media.

Huang, C. S., Yang, S. J., Chiang, T. H., \& Su, A. Y. (2016). Effects of situated mobile learning approach on learning motivation and performance of EFL students. Journal of Educational Technology \& Society, 19(1), 263-276.

Hyland, K. (2019). Second language writing. Cambridge University Press.

McNeely, R. (2015). Using humor in the Classroom: Luaghter has the power to fuel engagement and help students learn. National Education Association.

Neuman, S. B., Copple, C., \& Bredekamp, S. (2000). Learning to read and write: Developmentally appropriate practices for young children. National Association for the Education of Young Children.

Payne, A. R. (2012). Development of the academic writing motivation questionnaire.

Raja, R., \& Nagasubramani, P. C. (2018). Impact of modern technology in education. Journal of Applied and Advanced Research, 3(1), 33- 35.

Sugiyono, A. (2011). Metode Penelitian Kuantitatif, Kualitatif, dan $R \&$ D. Alfabeta.

Yustisia, N. (2012). Hypnoteaching Seni Ajar Mengeksplorasi Otak Peserta Didik. Arruz Media.

Zahro, I. F., Rohmalina, R., \& Nafiqoh, H. (2019). Studi Deskriptif Tentang Metode Hypnoteaching Pada Anak Usia Dini. Jurnal Tunas Siliwangi, 5(2), 6472. 